\title{
Biomarkers of environmental contaminants in field population of green mussel (Perna viridis) from Karnataka-Kerala coast (South West coast of India)
}

\author{
P. K. Krishnakumar - Geetha Sasikumar • \\ G. S. Bhat - D. P. K. Asokan
}

Accepted: 1 February 2006/Published online: 16 May 2006

(C) Springer Science+Business Media, LLC 2006

\begin{abstract}
The green mussel Perna viridis was sampled from relatively clean and contaminated sites along the Kartanata-Kerala coast (south west coast of India) to study the tissue concentration of trace metals and biological responses to stress (biomarkers) such as sister chromatid exchange (SCE), chromosomal aberration, micronucleus (MN) test, hemic neoplasia (HN), Chromotest (Ames test) and comet assay. In general, mean tissue concentrations of toxic trace metals collected from 25 sampling sites were found to be below the World Health Organisation (WHO) permissible concentration given for seafood. The digestive gland extract of mussels from all 25 sampling sites showed negative reaction for mutagenic activity (Ames test) in the absence of metabolic activation. Very low levels of chromosomal aberration, SCE, MN, $\mathrm{HN}$ and comet cells were observed in mussels collected from both the urban associated and relatively clean sites. This study seems to indicate that that the coastal waters of Karnataka and Kerala are minimally contaminated with genotoxic and carcinogenic chemicals.
\end{abstract}

Keywords Mussel - Perna viridis - Trace metals Sister chromatid exchange $\cdot$ Micronucleus $\cdot$ Hemic neoplasia $\cdot$ Ames test $\cdot$ Comet assay

\footnotetext{
P. K. Krishnakumar $(\square) \cdot$ G. Sasikumar - G. S. Bhat Mangalore Research Centre of Central Marine Fisheries Research Institute, Post Box No. 244, Bolar, Mangalore 575001 Kamataka, India

e-mail: krishnakumarpk@icqmail.com

D. P. K. Asokan

Calicut Research Centre of Central Marine Fisheries Research Institute, P.O. West Hill, Calicut, Kerala, India
}

\section{Introduction}

Marine bivalves are widely used as sentinel organisms for coastal pollution monitoring programs. Recent field studies have shown that some of these biomarkers of environmental contaminants in mussels can be used to discriminate between polluted and unpolluted sites (Krishnakumar et al. 1994, 1995). Cytogenetic techniques such as sister chromatid exchange (SCE), chromosomal aberration, Comet assay and micronucleus test have been used by several workers to assess the impact of environmental contaminants on marine mussels (Pavlica et al. 2000; Klobucar et al. 2003; Siu et al. 2004). The comet assay is a simple, sensitive, and versatile method for the detection of DNA damage in individual cells (Steinert 1999).

The green mussel, Perna viridis has a wide distribution along the west coast of India and this species has been proposed as sentinel organisms for marine pollution monitoring (Krishnakumar and Pillai 1990; Krishnakumar et al. 1998). Karnataka coast is well known for its abundant fishery resources particularly mackerel, oil sardine, prawns, perches, carangids, etc. The inshore waters of Karwar and Mangalore receive effluents from industries like the caustic soda plant, fertilizer plant, iron ore processing plant, dyes and pigment processing plant and a petroleum refinery. Coastal waters of Karwar, Mangalore and Calicut have been identified as pollution hotspots by the Central Pollution Control Board of India (CPCB 1996). Although there were some reports on bioaccumulation of toxic heavy metals in marine bivalves from Karnataka coast (Krishnakumar et al. 1998), studies on bioaccumulation of genotoxic chemicals and the biological effects on marine bivalves are lacking. In the present study an attempt is made (1) to biomonitor carcinogenic and mutagenic chemicals in the coastal environment using marine 


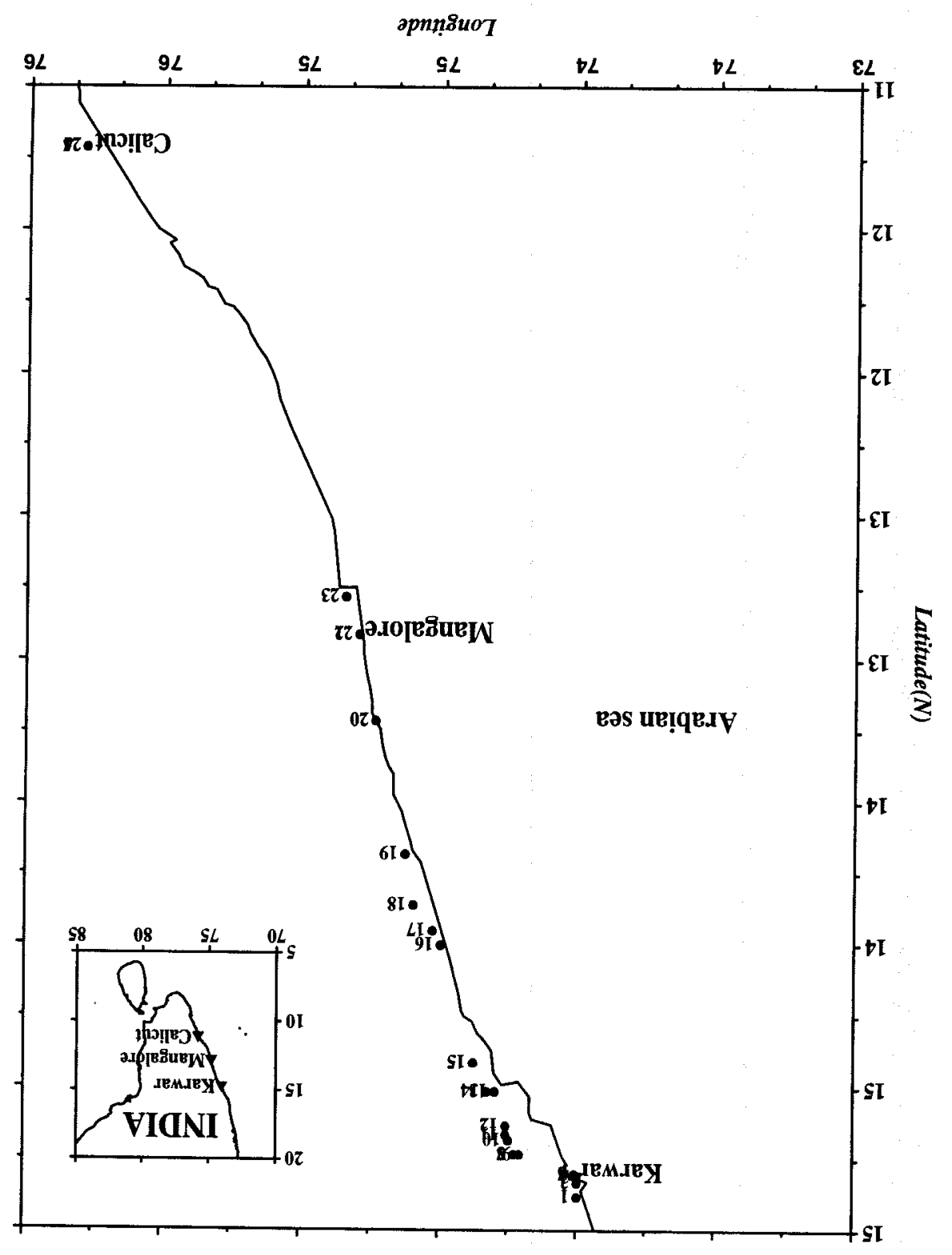

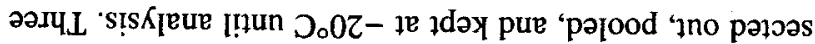

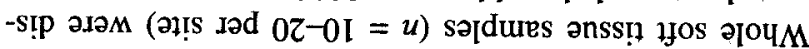

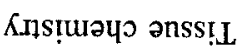

'sə!pm!s

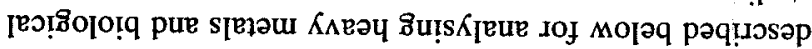

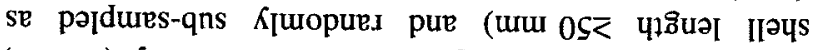

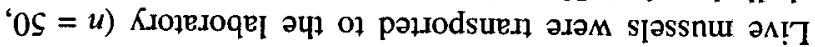

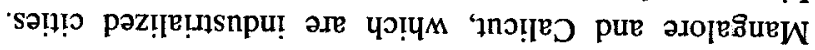

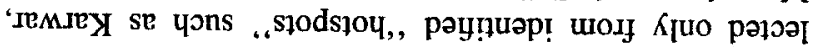
- ј00 әләм sıәу.reuro!̣ 8ut

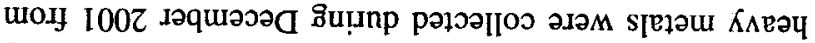

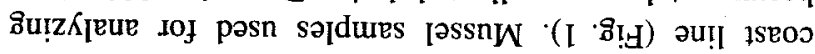

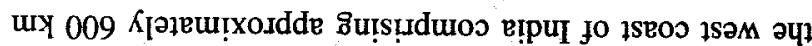

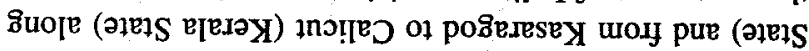

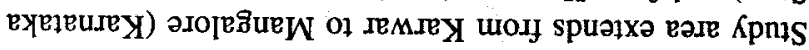

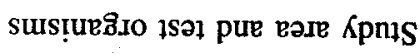

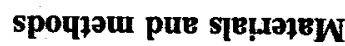

'vт̣pu jo

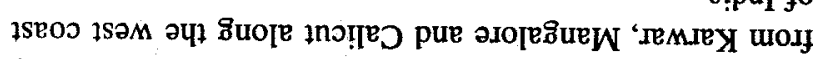

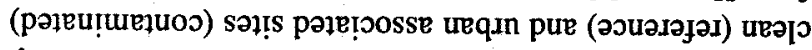

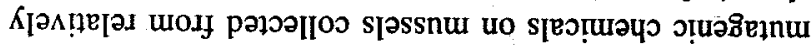

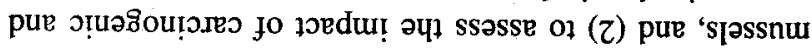


such batches were used for the analysis from each site. Toxic and essential elements in tissues were determined as described in Robisch and Clark (1993) using AAS. The results were expressed in $\mu \mathrm{g} \mathrm{g}^{-1}$ wet tissue weight.

\section{Chromosome analysis}

Preparation of the chromosomes was done according to the method of Dixon and Clarke (1982). Ten mussels were analysed from each site and the gill of each specimen was prepared on a separate slide. Well spread single metaphase chromosomes with few overlapping chromosomes were viewed using light microscope (Olympus BX50) with image analysis facility. Breaks and fragments in the chromosomes were counted as aberration. Sister chromatid exchange was scored and analysed following the methods reported by Dixon and Clarke (1982).

Micronucleus test (MN)

A 22-gauge hypodermic needle containing $0.5 \mathrm{ml}$ of TrisEDTA buffer was inserted between the valves and into the posterior adductor muscle to withdraw $0.2-0.5 \mathrm{ml}$ of hemolymph (Elston et al. 1988) and stained using the Schiff Feulgen-picromethyl blue procedure (Farley 1969). Slides were then microscopically examined for the presence or absence of hemic neoplasia (HN), as described by Krishnakumar et al. (1999).

\section{Comet assay}

Comet assay kit (Trevigen Inc., Gaithersburg, MD, USA) consisting of readymade comet slides and reagents was used to measure DNA damages in the digestive cells of mussels. Hemocytes were prepared for the assay as described by Steinert et al. (1998). Hemocytes at $1 \times 10^{5}$ per $\mathrm{ml}$ were combined with molten low melting point (LM) agarose (at $42^{\circ} \mathrm{C}$ ) at a ratio of $1: 10(\mathrm{v} / \mathrm{v})$ and immediately pipetted $50 \mu \mathrm{l}$ onto comet slide, and slides were placed flat at $4^{\circ} \mathrm{C}$ in the dark for $10 \mathrm{~min}$. Then the slides were immersed in prechilled lysine solution for $40 \mathrm{~min}$ at $4^{\circ} \mathrm{C}$. Slides were removed and immersed in freshly prepared alkali solution $(\mathrm{pH}>13$ ) for $20 \mathrm{~min}$ at room temperature in the dark to unwind the DNA under alkaline condition. The slides were transferred to a submarine gel electrophoresis chamber filled with $10 \mathrm{M}$ $\mathrm{NaOH}$ and $200 \mathrm{mM}$ EDTA $(\mathrm{pH}=10)$ and subjected to electrophoresis at $300 \mathrm{~mA}, 25 \mathrm{~V}$ for $15 \mathrm{~min}$. The comet slides were dipped in ethanol for $5 \mathrm{~min}$, air-dried and stained by placing $50 \mu \mathrm{l}$ diluted SYBR Green onto each circle of dried agarose on the slide. Slides were examined under epifluorescence at $200 \times$ magnification. SYBR
Green's maximum excitation and emission are 495 and $521 \mathrm{~nm}$ respectively. The comet tails in at least 30 cells were scored according to the DNA content such as nominal, medium, or high intensity tail.

Ames test (Chromotest)

From randomly selected mussel samples, digestive gland was dissected out and subjected to strong acid digestion using nitric acid and then diluted to $50 \mathrm{ml}$ using Millipore Ultrapure water. The extracts were neutralized to $\mathrm{pH} 7$ and tested using SOS-Chromotest Kit (Environmental Biodetection Products Inc., Brampton, Ontario, Canada) for genotoxicity. The test measures the increase in activity of E. coli's DNA repair system after exposure of the organism to genotoxicants (Quillardent et al. 1982) and gives negative or positive color indications.

\section{Statistical analysis}

One-way analysis of variance (ANOVA) was utilized to study the variations in concentrations of metals in mussel tissue (SPSS 12.00) from different sites.

\section{Result}

Bioaccumulation of trace metals

Concentrations of trace metals in the whole tissue of mussels ( $\mu \mathrm{g} \mathrm{g}^{-1}$ wet $\mathrm{wt}$ ) together with the results of SOSChromotest using mussel digestive gland extract from 25 sites collected during December 2001 are shown in Table 1. Distribution of metals in mussel tissue between the sites was found to be statistically not different (ANOVA test). Mean tissue concentrations of toxic trace metals collected from 25 sampling sites were found to be below the WHO permissible concentration given for seafood (WHO 1987). Tissue concentrations of $\mathrm{Fe}$ in the samples varied from 15.7 to $286.5 \mu \mathrm{g} \mathrm{g}^{-1}, \mathrm{Cu}$ from 0.08 to $3.46 \mu \mathrm{g} \mathrm{g}^{-1}$, Ni from below the detection limit (nd) to $2.89 \mu \mathrm{g} \mathrm{g}^{-1}, \mathrm{Cd}$ from nd to $2.99 \mu \mathrm{g} \mathrm{g}^{-1}, \mathrm{Cr}$ from nd to $2.83 \mu \mathrm{g} \mathrm{g}^{-1}, \mathrm{Zn}$ from 7.47 to $42.98 \mu \mathrm{g} \mathrm{g}^{-1}$ and $\mathrm{Mn}$ from 3.14 to $18.29 \mu \mathrm{g} \mathrm{g}^{-1}$. Tissue concentrations of $\mathrm{Pb}$ in the samples were below the detection limit. Tissue concentrations of Cd from two sites (urban sites from Mangalore and Calicut), $\mathrm{Ni}$ from three sites (in and around Karwar) and $\mathrm{Cr}$ from one site (Calicut urban) slightly exceeded the WHO permissible concentration given for seafood.

Relatively high concentrations of $\mathrm{Cu}, \mathrm{Cd}, \mathrm{Cr}, \mathrm{Zn}$ and Mn were observed in mussel samples collected from Calicut (Table 1). Mean heavy metal concentration in 
Table 1 Trace metal concentration in the whole tissue ( $\mu \mathrm{g} \mathrm{g}^{-1}$ wet tissue weight) of green mussel Perna viridis sampled from 25 sites along Karnataka-Kerala coast (west coast of India) during
December 2001 December 2001

\begin{tabular}{|c|c|c|c|c|c|c|c|c|c|c|}
\hline S. No. & Site & $\mathrm{Fe}$ & $\mathrm{Cu}$ & $\mathrm{Ni}$ & $\mathrm{Cd}$ & $\mathrm{Cr}$ & $\mathrm{Zn}$ & $\mathrm{Pb}$ & Mn & $\begin{array}{l}\text { SOS- } \\
\text { chromotest }\end{array}$ \\
\hline 1 & Majali Kurumgad & $92.4 \pm 40.7$ & $1.402 \pm 0.49$ & nd & $1.142 \pm 0.14$ & nd & $10.06 \pm 0.08$ & nd & $8.765 \pm 1.12$ & Negative \\
\hline 2 & Island Bhicanasi & $218.6 \pm 16.9$ & $1.386 \pm 0.19$ & $2.868 \pm 0.01$ & $0.285 \pm 0.05$ & $0.145 \pm 0.06$ & $7.47 \pm 0.90$ & nd & $10.495 \pm 0.43$ & Negative \\
\hline 3 & Island & $259.4 \pm 22.6$ & $1.667 \pm 0.08$ & $2.407 \pm 0.15$ & $0.99 \pm 0.61$ & $0.179 \pm 0.07$ & $14.08 \pm 1.06$ & nd & $7.646 \pm 0.18$ & Negative \\
\hline 4 & Karwar & $32.6 \pm 11.9$ & $1.896 \pm 0.34$ & nd & $0.218 \pm 0.17$ & nd & $12.41 \pm 1.88$ & nd & $6.969 \pm 1.79$ & Negative \\
\hline 5 & Ladies beach & $39.1 \pm 2.26$ & $1.84 \pm 0.08$ & $2.887 \pm 0.15$ & $0.538 \pm 0.61$ & $0.117 \pm 0.07$ & $13.23 \pm 1.06$ & nd & $6.877 \pm 0.18$ & Negative \\
\hline 6 & Harwada & $235.6 \pm 22.4$ & $1.572 \pm 1.07$ & nd & $1.683 \pm 0.07$ & nd & $9.06 \pm 1.22$ & nd & $7.021 \pm 0.01$ & Negative \\
\hline 7 & Mudga & $165.2 \pm 66.2$ & $1.447 \pm 0.37$ & $1.435 \pm 0.44$ & $1.825 \pm 0.12$ & $0.185 \pm 0.27$ & $14.08 \pm 1.81$ & nd & $7.986 \pm 1.75$ & Negative \\
\hline 8 & Baraekal & $113.3 \pm 5.2$ & $1.774 \pm 0.10$ & $1.26 \pm 0.22$ & $0.181 \pm 0.07$ & $0.231 \pm 0.08$ & $8.39 \pm 7.7$ & nd & $6.067 \pm 0.10$ & Negative \\
\hline 9 & Bawathikatta & $51.4 \pm 5.2$ & $1.332 \pm 0.10$ & $1.772 \pm 0.44$ & $0.158 \pm 0.07$ & nd & $10.02 \pm 4.8$ & nd & $7.918 \pm 0.17$ & Negative \\
\hline 10 & Belekeri & $117.1 \pm 29.5$ & $0.886 \pm 0.17$ & nd & $0.322 \pm 0.01$ & nd & $17.35 \pm 9.37$ & nd & $5.225 \pm 0.44$ & Negative \\
\hline 11 & Ankola & $286.5 \pm 57.2$ & $1.335 \pm 0.06$ & nd & $0.24 \pm 0.05$ & $0.141 \pm 0.13$ & $16.91 \pm 4.98$ & nd & $5.686 \pm 0.86$ & Negative \\
\hline 12 & Belambar & $118.9 \pm 16.3$ & $0.999 \pm 0.01$ & nd & $1.211 \pm 0.52$ & nd & $16.18 \pm 11.8$ & nd & $4.258 \pm 0.17$ & Negative \\
\hline 13 & Gokarna & $86.6 \pm 33.8$ & $1.181 \pm 0.31$ & nd & $0.378 \pm 0.10$ & nd & $11.51 \pm 6.75$ & nd & $6.2 \pm 1.69$ & Negative \\
\hline 14 & Tadri & $61.7 \pm 37.9$ & $1.058 \pm 0.30$ & nd & $1.702 \pm 0.28$ & nd & $21.57 \pm 20.4$ & nd & $5.667 \pm 0.59$ & Negative \\
\hline 15 & Kumta & $93.5 \pm 17.2$ & $1.259 \pm 1.03$ & nd & $1.535 \pm 0.35$ & nd & $11.7 \pm 24.0$ & nd & $7.323 \pm 0.31$ & Negative \\
\hline 16 & Jali & $61.8 \pm 19.1$ & $0.757 \pm 0.43$ & nd & $1.471 \pm 0.07$ & nd & $8.7 \pm 2.63$ & nd & $6.339 \pm 0.85$ & Negative \\
\hline 17 & Bhatkal & $48.4 \pm 19.0$ & $0.453 \pm 0.55$ & nd & $1.177 \pm 1.61$ & nd & $8.02 \pm 0.58$ & nd & $6.409 \pm 0.52$ & Negative \\
\hline 18 & Someshwara & $15.7 \pm 18.6$ & $0.797 \pm 0.26$ & $1.675 \pm 0.45$ & $0.324 \pm 0.18$ & nd & $10.15 \pm 1.92$ & nd & $3.138 \pm 2.06$ & Negative \\
\hline 19 & Byndoor & $73.9 \pm 52.7$ & $1.169 \pm 0.12$ & $0.276 \pm 0.09$ & $1.613 \pm 0.48$ & $0.081 \pm 0.02$ & $8.95 \pm 1.59$ & nd & $5.912 \pm 1.65$ & Negative \\
\hline 20 & Trasi & $91.2 \pm 17.9$ & $0.891 \pm 0.46$ & nd & $1.303 \pm 0.27$ & nd & $12.31 \pm 3.38$ & nd & $3.636 \pm 0.87$ & Negative \\
\hline 21 & Kaup & $34.2 \pm 39.9$ & $1.537 \pm 0.27$ & $1.211 \pm 0.13$ & $0.689 \pm 0.12$ & 0.393 & $10.57 \pm 2.08$ & nd & $3.547 \pm 0.22$ & Negative \\
\hline 22 & Mangaloreurban & $86.4 \pm 25.3$ & $1.021 \pm 0.16$ & nd & $2.988 \pm 0.27$ & nd & $9.48 \pm 0.50$ & nd & $3.25 \pm 0.74$ & Negative \\
\hline 23 & Mangalorerural & $90 \pm 62.3$ & $0.08 \pm 0.12$ & nd & $0.54 \pm 0.16$ & $0.02 \pm 0.08$ & $9.72 \pm 0.48$ & nd & $3.56 \pm 1.04$ & Negative \\
\hline 24 & Calicuturban & $85.2 \pm 9.73$ & $3.464 \pm 0.13$ & nd & $2.834 \pm 2.06$ & $2.83 \pm 2.19$ & $42.98 \pm 7.22$ & nd & $18.29 \pm 0.54$ & Negative \\
\hline \multirow[t]{2}{*}{25} & Calicutrural & $16.6 \pm 2.80$ & $1.077 \pm 0.10$ & nd & nd & nd & $27.27 \pm 18.95$ & nd & $4.737 \pm 0.62$ & Negative \\
\hline & $\begin{array}{l}\text { *WHO } \\
\text { permissible } \\
\text { concentration }\end{array}$ & - & 30 & 2 & 2 & 2 & 50 & 2 & - & \\
\hline
\end{tabular}

The results of chromotest (Ames test) carried out using the digestive gland extract of mussels from the above sites are given in the last column

*WHO $(1972,1987)$ 
mussels exhibited the following decreasing order of concentration, $\mathrm{Fe}>\mathrm{Zn}>\mathrm{Mn}>\mathrm{Cu}>\mathrm{Cd}>\mathrm{Ni}>\mathrm{Cr}>\mathrm{Pb}$. Tissue concentrations of heavy metals were generally higher in mussels from the urban-associated sites like Calicut urban, Mangalore urban and some of the sites in and around Karwar. Similar observations were made by earlier researchers using mussels and oysters as indicator organisms from the above locations (Krishnakumar et al. 1998). The digestive gland extract of mussels from all 25 sampling sites showed negative reaction for mutagenic activity (SOS-Chromotest) in the absence of metabolic activation.

\section{Biological study}

Results of \% occurrence of chromosomal aberration, sister chromatid exchange (SCE), \% occurrence of $\mathrm{MN}, \%$ occurrence of comet and $\mathrm{HN}$ in mussels collected from the contaminated and relatively clean sites from Karwar, Mangalore and Calicut are shown in Table 2. Very low \% occurrence of chromosomal aberration and SCE varying from 0 to 3 was observed in mussels collected from the reference sites and contaminated sites. Hemic neoplasia was not observed in any of the mussels collected from the above sites and \% occurrence of micronuclei was varying from 0 to 1 from all sites. Low $\%$ occurrence of comet cells $(8-11 \%)$ was observed in mussels collected from all sites.

\section{Discussion}

Cytogenetic techniques such as SCE, chromosomal aberration, comet assay and micronucleus test have been used by several researchers to assess the impact of environmental contaminants on marine mussels (Shugart et al. 1992; Steinert 1999; Pavlica et al. 2000; Klobucar et al. 2003; Siu et al. 2004). This is the first field report on the biological responses (chromosomal aberration, SCE, micronuclei formation, hemic neoplasia and DNA damage) of field populations of green mussels collected from Indian waters to carcinogenic and mutagenic chemicals.

Previous studies have identified heavy metal contamination of the coastal environment from these areas (Krishnakumar and Pillai 1990; Krishnakumar et al. 1998). A caustic soda plant situated at Karwar is disposing its effluent containing mercury into the sea near Benaga beach at Karwar (Krishnakumar and Pillai 1990). Several industries (refinery, fertilizer plant, dye manufacturing plant, iron ore processing plant, etc.) are dumping their treated effluent into the sea off Mangalore. A pulp rayon factory was disposing its effluent into the sea off Calicut until recently. The present study has shown that the tissue concentrations of toxic trace metals in mussels from the west coast of India are relatively low (Table 1). Generally, the biological responses (biomarkers) of natural populations of mussels collected from the urban associated sites from Karwar, Mangalore and Calicut, along the west coast of India were found to be within the normal range and no indication of stress was observed (Table 2). The results of the Chromotest (Ames test) also showed that levels of genotoxic and carcinogenic chemicals in their tissue were very low (Table 2).

A number of studies have demonstrated that marine mussels are suitable for the detection of genotoxic agents (Wilson et al. 1998; Steinert et al. 1998; Klobucar et al. 2003). Comet assay using Mytilus edulis from San Diego Bay was found to respond rapidly to environmental contaminants (Steinert et al. 1998). Rank and Jensen (2003) performed comet assays on $M$. edulis hemolymph and gill cells exposed to contaminants and found that, although both tissues were equally sensitive to contaminants, hemolymph was better for in vivo studies because it was much simpler to collect and handle. Wilson et al. (1998) observed that the comet assay using $M$. edulis has more potential for use in an in vitro context for the screening agents for disposal into the marine environment. Induction of SCE in $M$. galloprovincialis was studied under field conditions (Al-Sabati and Kurelec 1985). However under relatively clean field conditions, most of these biomarkers

Table 2 Occurrence of chromosomal aberration, sister chromatid exchange, micronucleus, hemic neoplasia and DNA damage (comet assay) in green mussel Perna viridis $(n=20)$ sampled from "hotspots" along Karnataka- Kerala coast (west coast of India)

\begin{tabular}{|c|c|c|c|c|c|c|}
\hline Site & Site category & $\begin{array}{l}\text { Chromosomal } \\
\text { aberration } \\
\text { (\% occurrence) }\end{array}$ & $\begin{array}{l}\text { Sister chromatid } \\
\text { exchange (SCE) } \\
\text { (\% occurrence) }\end{array}$ & $\begin{array}{l}\text { Micronucleus test }(\mathrm{MN}) \\
\text { (\% occurrence) }\end{array}$ & $\begin{array}{l}\text { Haemic } \\
\text { neoplasia } \\
\text { (\% prevalence) }\end{array}$ & $\begin{array}{l}\text { Comet assay } \\
\text { (\% occurrence) }\end{array}$ \\
\hline \multirow[t]{2}{*}{ Karwar } & Reference & $2 \pm 0.3$ & $1 \pm 0.1$ & 0 & 0 & $8 \pm 1$ \\
\hline & Contaminated & $3 \pm 0.7$ & $2 \pm 0.3$ & 0 & 0 & $9 \pm 3$ \\
\hline \multirow[t]{2}{*}{ Mangalore } & Reference & $2 \pm 0.4$ & 0 & $1 \pm 0.1$ & 0 & $10 \pm 2$ \\
\hline & Contaminated & $3 \pm 0.8$ & 0 & 0 & 0 & $11 \pm 4$ \\
\hline \multirow[t]{2}{*}{ Calicut } & Reference & $3 \pm 0.6$ & $2 \pm 0.4$ & $1 \pm 0.2$ & 0 & $10 \pm 2$ \\
\hline & Contaminated & $3 \pm 0.8$ & 0 & $1 \pm 0.4$ & 0 & $9 \pm 3$ \\
\hline
\end{tabular}


in marine mussels will be either below the detection limits or less sensitive.

Earlier chemical monitoring studies also have shown that Karnataka and Kerala coast were not contaminated with any organic chemicals (CPCB 1996). Very low levels of chromosomal aberration, SCE, $\mathrm{MN}$ and $\mathrm{HN}$ were observed in mussels collected from both the urban associated and relatively clean sites. Similarly, the \% occurrence of comet cells in mussels collected from the urban associated and relatively clean sites were also in the same range (Table 2). Except for a few sites industrial activities are not located along the Karnataka-Kerala coast. The results of the present study show that at the present level of industrialization the coastal waters of Karnataka and Kerala are minimally contaminated with genotoxic and carcinogenic chemicals.

Acknowledgments The work described in this paper was supported by a grant from the International Foundation for Science (IFS), by a grant from the Inarded to the first author (grant no. A/2714-1). Stockholm, Sweden, awarded to the first aut Dr. Mohan Joseph Modayil for his encouragement and providing facilities. We are also thankful to Dr. M. Rajagopalan, Head of FEM Division and Dr. C. Muthiah, Scientist-in-Charge, RC of CMFRI, Mangalore for their valuable help and suggestion.

\section{References}

Al-Sabati K, Kurelec B (1985) Induction of chromosomal aberrations in the mussel Mytilus galloprovincialis Watch. Bull Environ Contam Toxicol 35:660-665

Central Pollution Control Board (CPCB) (1996) Coastal pollution. (Technical publication) Govt. of India, New Delhi, $30 \mathrm{pp}$

Dixon DR, Clark KR (1982) Sister chromatid exchange: a sensitive technique for detecting damage caused by exposure to environmental mutagens in the chromosomes of adult Mytilus edulis. Mar Biol Lett 3:163-172

Elston RA, Kent ML, Drum AS (1988) Progression, lethality and remission of hemic neoplasia in the bay mussel Mytilus edulis. Dis Aquat Org 4:135-142

Farley CA (1969) Probable neoplastic disease of the hematopoietic system in oysters, Crassostrea virginica and Crassostrea gigas. Nat Cancer Inst Monogr 31:541-555

Klobucar GIV, Palvica M, Erben R, Papes D (2003) Application of micronucleus and comet assays to mussel Dreissena polymorpha haemocytes for genotoxicity monitoring of freshwater environments. Aquat Toxicol 64:15-23

Krishnakumar PK, Casillas E, Varanasi U (1994) Effects of environmental contaminants on the health of Mytilus edulis from Puget sound, Washington, USA. I. Cytochemical measures of lysosomal responses in the digestive cells using automatic image analysis. Mar Ecol Prog Ser 106:249-261
Krishnakumar PK, Casillas E, Varanasi U (1995) Effects of environmental contaminants on the health of Mytilus edulis from Puget sound, Washington, USA. II. Cytochemical detection of subcellular changes in the digestive cells. Mar Biol 124:251-259

Krishnakumar PK, Bhat GS, Vaidya NG, Pillai VK (1998) Heavy metal distribution in the coastal waters of Karnataka, west coast of India. Indian J Mar Sci 27:201-205

Krishnakumar PK, Casillas E, Snider RG, Varanasi U (1999) Environmental contaminants and the prevalence of hemic neoplasia (leukemia) in the common mussel (Mytilus edulis complex) from Puget Sound, Washington, USA. J Invertebr Pathol 73:135-146

Krishnakumar PK, Pillai VK (1990) Mercury near a caustic soda plant at Karwar, India. Mar Pollut Bull 21:304-307

Palvica M, Klobucar GIV, Vetma N, Erben R, Papes D (2000) Detection of micronuclei in haemocytes of zebra mussel and great ramshorn snail exposed to pentachlorophenol. Mut Res 465:145-150

Quillardent P, Huismon OR, Hofnung M (1982) SOS-Chromotest, a direct assay of induction of a SOS function in $E$ coli $\mathrm{K}-12$ to measure toxicity. Proc Nat Acad Sci USA 79:5971-5975

Rank J, Jensen K (2003) Comet assay on gill cells and hemocytes from the blue mussel Mitylus edulis. Ecotoxicol Environ Saf 54:323-329

Robisch PA, Clark RC (1993) Sample preparation and analyses of trace metals by atomic absorption spectroscopy. In: Lauenstein GG, AY Cantillo (eds) Sampling and analytical methods of the National Status and Trends Program National Benthic Surveillance Program and Mussel Watch Project 1984-1992, vol III, Comprehensive description of elemental analytical methods. NOAA Tech Memo, NOS ORCA 71, pp 111-150

Shugart L, Bickman J, Jackim E, McMahon G, Ridley W, Stein J, Steinert SA (1992) DNA alterations. In: Hugget RJ, Kimerle RA, Mehrle PM Jr, Bergman HL (eds) Biomarkers: biochemical, physiological, and histological markers of anthropogenic stress. Lewis Publishers, Chelsea MI, pp 125-153

Siu WHL Cao J, Jack RW, Wu RSS, Richardson BJ, Xu L, Lam PKS (2004) Application of the comet and micronucleus assays to the detection of $B[a] P$ genotoxicity in hemocytes of the green-lipped mussel (Perna viridis). Aquat Toxicol 66:381-392

Steinert SA, Streib-Montee R, Leather JM, Chadwick DB (1998) DNA damage in mussels at sites in San Diego Bay. Mut Res $399: 65-85$

Steinert SA (1999) DNA damage as bivalve biomarker and as an environmental assessment tool. Biomarkers 4(6):492

WHO (World Health Organisation) (1987) Evaluation of certain food additives and contaminants. Thirty-third report of the joint $\mathrm{FAO} /$ WHO expert committee on food additives. WHO Technical Report Series 776, Geneva, 80 pp

Wilson LJ, Pascoe PL, Parry JM, Dixon DR (1998) Evaluation of the comet assay as a method for the detection of DNA damage in the cells of a marine invertebrate, Mytilus edulis L (Mollusca: Pelecypoda) Mut Res 399:87-95 